\title{
ROCKFALL HAZARD AND RISK ASSESSMENT ON FORESTED SLOPES, EXAMPLES FROM CZECHIA
}

\begin{abstract}
KLIMEŠ, J. (2011): Rockfall hazard and risk assessment on forested slopes, examples from Czechia. Geografie, 116, No. 2, pp. 144-155. - Rockfall hazard is assessed using Rockfor.net, which is one dimensional tool for assessing the protective function of forests against rockfall. Three sites where chosen to test the tool with different morphological and forest conditions. For each site, it was evaluated how the boulder size and forest composition affects the probability of the rocks to surpass the forested slope. The Rockfor. net was also used for back calculations of past event, which happened during the floods in July 1997 in the village of Bystřčcka in the Vsetínské vrchy Hills. In this case, also a partial quantitative risk assessment with suggestions for risk management was performed.

KEY WORDS: landslide hazard and risk - rockfalls - Rockfor.net - flysh rocks - Cretaceous sandstones.
\end{abstract}

Author thanks to the grant project GA ČR No. 205/09/P383 for financial support and Luuk Dorren for help with manuscript preparation.

\section{Introduction}

Rockfalls do not belong to the most frequent type of slope movements within Czechia and their occurrence is mostly constrained to a few regions represented by Cretaceous sandstone areas with developed rock cities, pseudokarst and karst areas. Locally, rockfalls also occur in glacial cirques of the Krkonoše or Šumava Mts. and scarp areas of deep-seated slope deformation in Beskydy Mts. Despite limited occurrence, rockfalls represent one of the potentially most dangerous slope failures, since they can cause high damage even if a single boulder is involved in the movement. Therefore considerable attention has always been paid to mitigate rockfalls in inhabited areas where also expert hazard assessment has been conducted (Zvelebil 1989). In the last decades, very sophisticated methods of rockfall monitoring and early warning as a part of risk management have been applied in some of those areas (Zvelebil, Vařilová, Palus 2005, 2008). Sophisticated and technologically advanced monitoring system may be applied only on selected sites thus rockfalls still threaten large areas included inhabited areas. Unexpected $9 \mathrm{~m}^{3}$ rockfall in the town of Hřensko, which occurred on 15.10 .2009 (www.novinky.cz) is one example of such a dangerous events. They can not be completely mitigated since represent natural rock slope development of broad areas (Hartvich, Rybár 2011). Physically based models describing behavior of falling rocks including probability calculation of the maximum travel distance or velocities (Guzzetti et al. 2002), which can be applied for rockfall hazard mapping on regional scale 


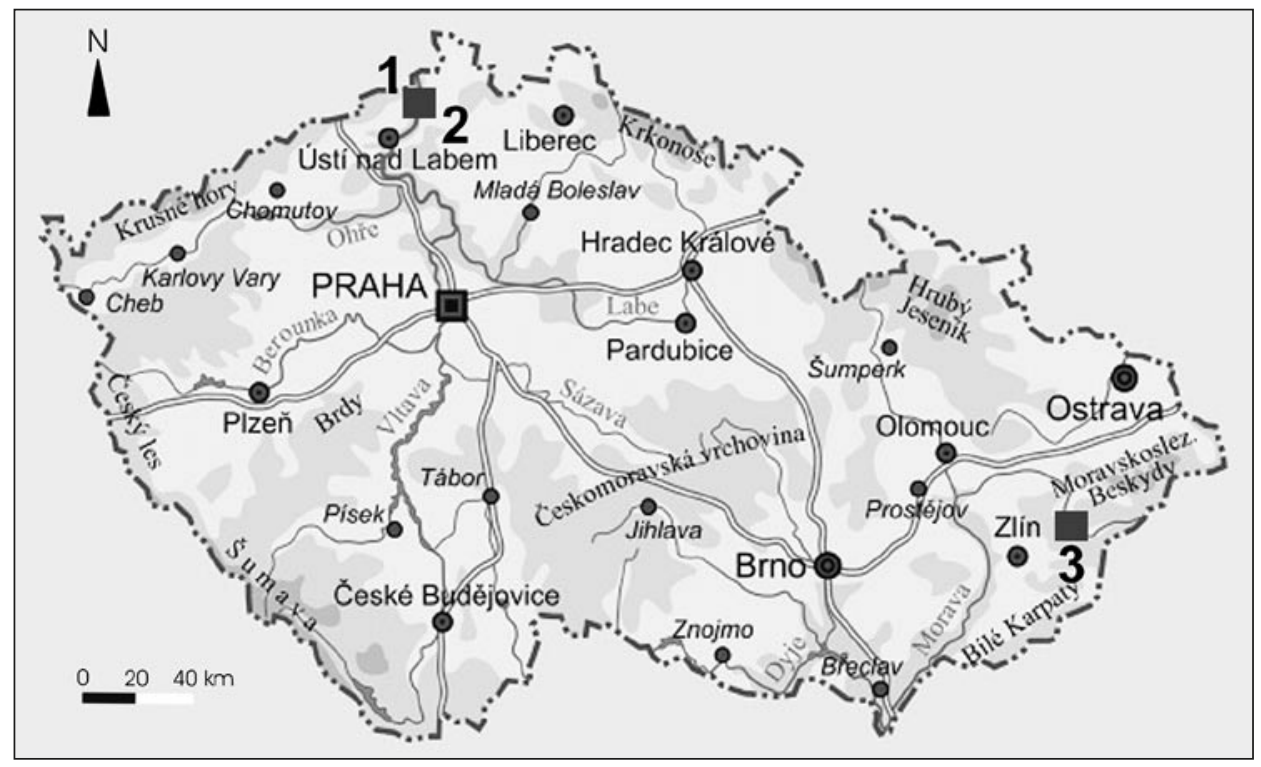

Fig. 1 - Location of studied sites: 1 - Suchá Kamenice, 2 - Obecní důl, 3 - Bystřička.

have not been used in Czechia yet. The presented paper contributes to this field by application of the Rockfor.net web tool designed by Berger and Dorren (2007) for rapid, minimum input parameters assessment of rockfall hazard. It was applied to forested slopes at two sites south of the town of Hřensko, North Bohemia and one site near the Bystřička dam in Moravia (Fig. 1).

\section{Rockfor.net description}

There are numerous programs modeling rockfall trajectories and run out zones on slope scale or on regional scale. They can be divided into empirical, process and GIS-based models (Dorren 2003). Empirical models are based on observed relationship between topographical factors and run-out zones of the rockfalls. They are also referred as statistical models. Process-based models simulate the motion of boulders over slope surface and are often implemented into GIS environment. Moreover some private companies producing rockfall protecting barriers are developing their own softwer, which serve in barrier design on specific slopes.

The Rockfor.net program combines process-based model with empirical approach. It is easy to use, freely available tool for assessing the protective function of forest against rockfalls. In this model, forest acts as sequence of open rockfall nets consisting of rows of trees (referred as curtains). Rockfor. net calculates total energy developed by a falling rock of given characteristics (size, shape and rock type) and number of curtains required for dissipating the total energy acquired by the falling rock fragment (Berger, Dorren 2007). The required number of curtains is converted into a required total basal area using the mean diameter at breast height $(\mathrm{DBH})$ of trees on a site. Then 
Rockfor.net calculates the basal area theoretically encountered by the rock when it falls through the given forest characterized by tree species composition and the total basal area. The total basal area can be entered as a value per ha or it can be calculated by the tool using the mean DBH and the stem density. The protective role of forest is quantified by comparing the required basal area with theoretically encountered basal area giving probable rockfall hazard (PRH), i.e., the percentage of rocks that surpass the forested zone on a given slope (Berger and Dorren 2007). In addition the freely available web version of Rockfor.net (www.ecorisq.org/en/rockfornet.php) provides user with required stand density and required mean $\mathrm{DBH}$ in order to obtain a $\mathrm{PRH}$ of 1\% (Berger, Dorren 2007) for the given slope. In addition to the PRH, Rockfor. net calculates the required DBH and stand density for stopping al the rocks at the given slopes. This is done on the basis of the required total basal area and can result in very unrealistic values (for example, 5,000 trees per ha with a mean DBH of 30-40 cm). In such cases, Rockfor.net shows that the forest will never be able to protect a give site against the given rock size. It is important to note that the model is best suited for one typical morphological setting - a rock cliff grading down to a relatively straight slope covered by a homogenous forest (Berger, Dorren 2007). Surface roughness or flat areas on a slope are not included into the calculation as energy dissipation features. The model predicted satisfactorily for sites where all rocks would be stopped by the forest ( $\mathrm{PRH}=1 \%)$ or $25 \%, 50 \%$ or more than $75 \%$ of the rocks would pass the forest (Berger, Dorren 2007).

\section{Input data and methods}

The three chosen test sites have different forest characteristics and represent different rockfall mechanisms. Two of them lie in the Upper Cretaceous Bílá hora Formation sandstone layers in the Labe River canyon, in the Děčínská vrchovina Highland, near the town of Hřensko (Fig. 1). One of them, the Obecní důl site, represents the area of catastrophic rockfall in the spring of 1978 (Zvelebil 1989) during which the total volume of 2,700 $\mathrm{m}^{3}$ of rock failed and consequently, boulders with volume 30 and $40 \mathrm{~m}^{3}$ passed through forest to the Labe River watercourse (Zvelebil 1989). The third site is located in the Rusava Member sandstone layers (Eocene) of the Magura flysh nappe near the Bystřička dam, Bystřička Village, Vsetínské vrchy Hills (Fig. 1). The sites in the Děčínská vrchovina Highland represent typical rockfall conditions where the boulders fall from an almost vertical cliff (Fig. 2) to the slope below, whereas at the Bystřička site the boulders rolled out from the accumulation of a shallow (about $3 \mathrm{~m}$ deep) translational landslide (Fig. 3 ), during its active movement on July 6th 1997 . The landslide was caused by extreme precipitation (Hladký ed. 1998). Basic morphological and vegetation characteristics (Fig. 4) of the sites were acquired in the field (Table 1). In the Bystřička case, literature information about location, causes and size of fallen rock were also used (Kirchner, Krejčí 1997). The $P R H$ values were calculated for four different boulder sizes representing historical rockfalls (Kirchner, Krejči 1997) or typical rock size found on the slopes of the test sites. 


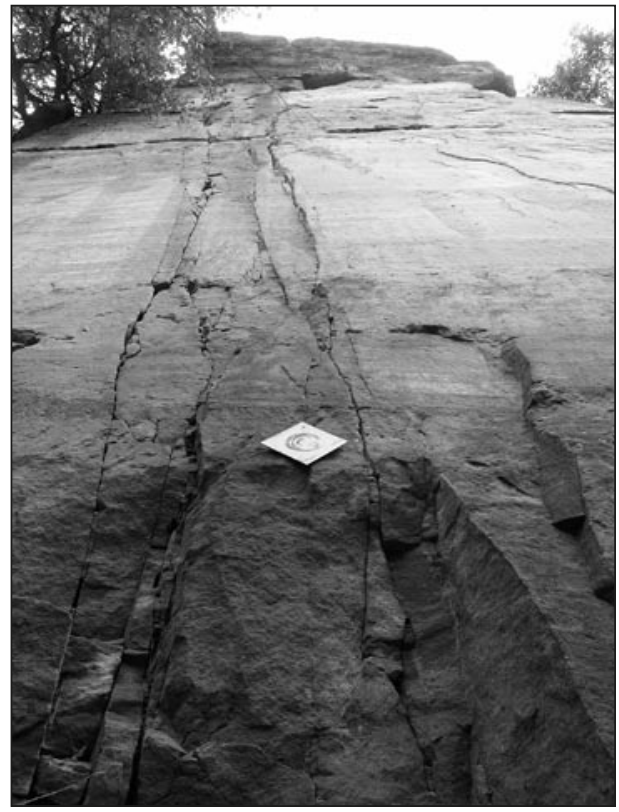

Fig. 2 - Detailed view of the sandstone cliff at the Obecní důl site

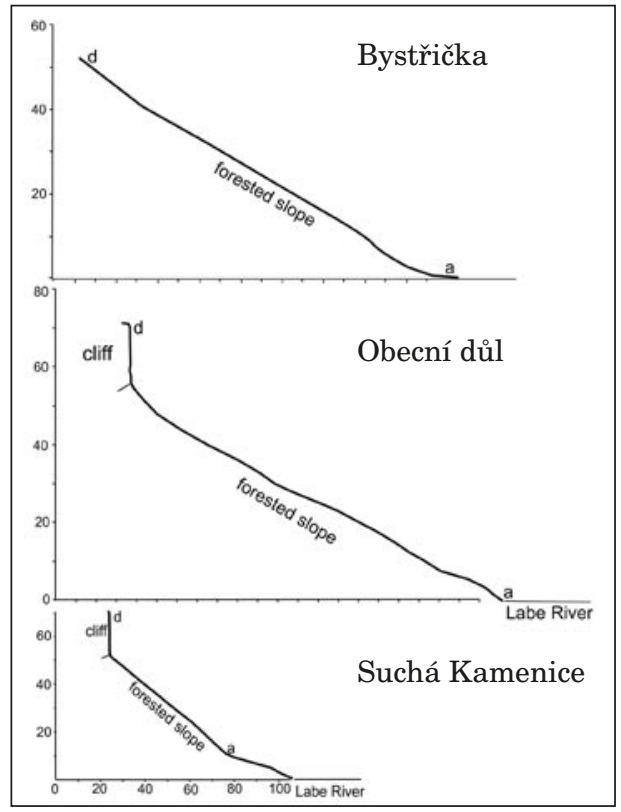

Fig. 3 - Topographic profiles of the study sites with detachment (d) and accumulation (a) zones

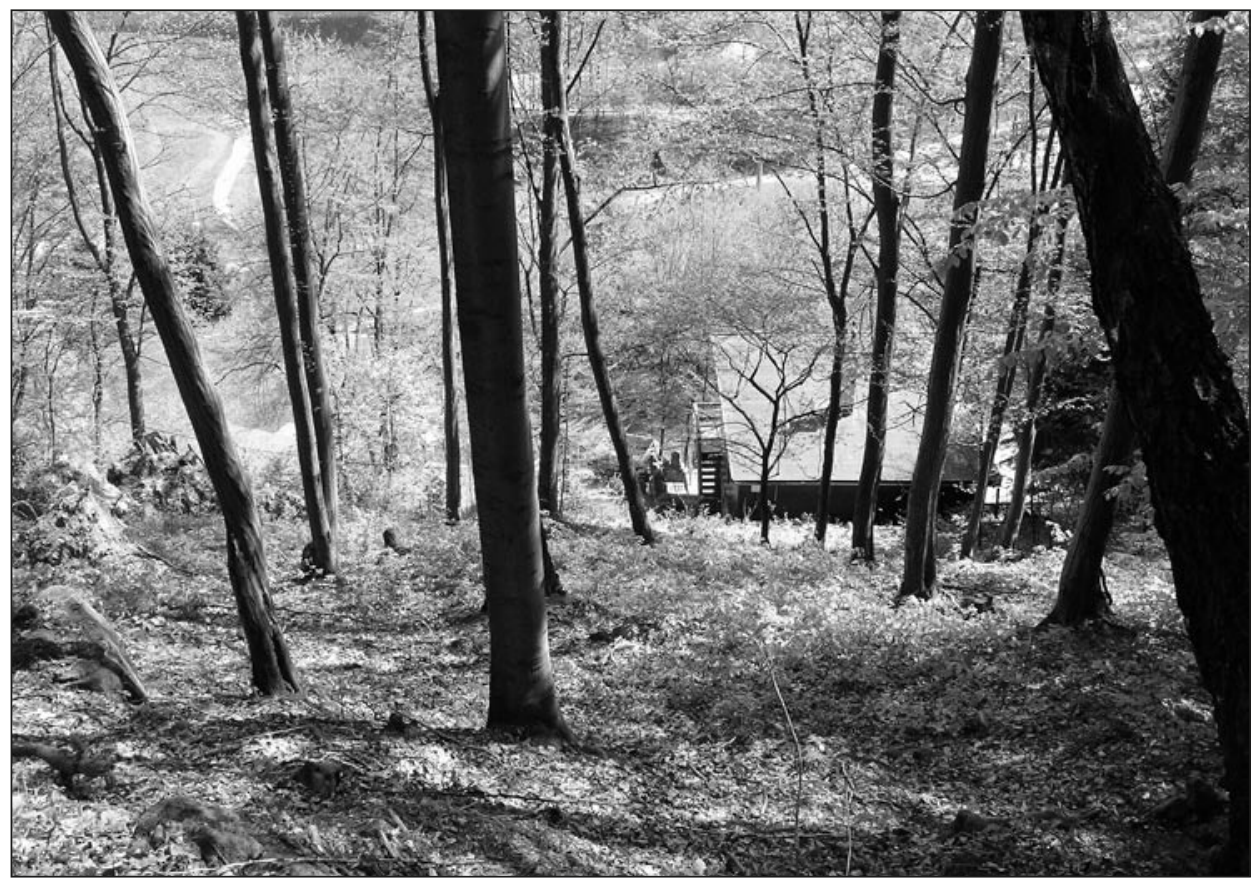

Fig. 4 - Down slope view on the forest and endangered houses at the Bystřička site 


\begin{tabular}{|c|c|c|c|c|c|c|c|c|c|c|}
\hline 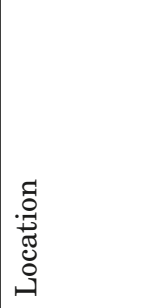 & 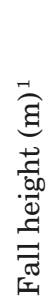 & 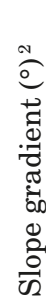 & 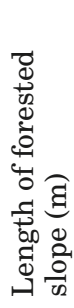 & 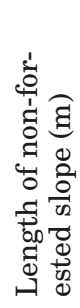 & 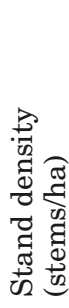 & 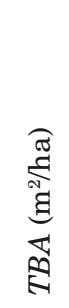 & 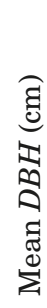 & 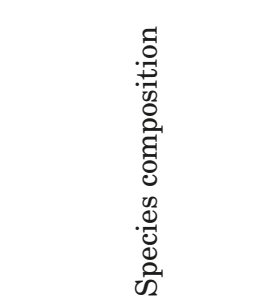 & 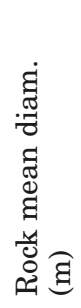 & 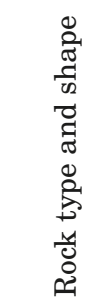 \\
\hline $\begin{array}{l}\text { Obecní } \\
\text { důl }\end{array}$ & 30 & 29 & 140 & 0 & 842 & 14.9 & 15 & $\begin{array}{l}\text { Picea sp. }-38 \% \\
\text { Pinus sp. }-18 \% \\
\text { Fagus sp. }-1 \% \\
\text { Betula sp. }-43 \%\end{array}$ & 1 & \multirow[t]{3}{*}{$\begin{array}{l}\text { Sand- } \\
\text { stone/ } \\
\text { sphere }\end{array}$} \\
\hline $\begin{array}{l}\text { Suchá } \\
\text { Kamenice }\end{array}$ & 17 & 26 & 96 & 0 & 489 & 32.3 & 29 & $\begin{array}{l}\text { Picea sp. }-36 \% \\
\text { Pinus sp. }-7 \% \\
\text { Fagus sp. }-50 \% \\
\text { Betula sp. }-4 \% \\
\text { Acer sp. }-3 \%\end{array}$ & 1 & \\
\hline Bystřička & 0 & 38 & 134 & 0 & 89 & 14.8 & 46 & $\begin{array}{l}\text { Picea sp. }-21 \% \\
\text { Pinus sp. }-0 \% \\
\text { Fagus sp. }-54 \% \\
\text { Betula sp. }-0 \% \\
\text { Carpinus sp. }-25 \%\end{array}$ & 2,1 & \\
\hline
\end{tabular}

Note: $P R H$ - Probable Rockfall Hazard; TBA - total basal area; ${ }^{1}$ height from the boulder detachment point to its impact on the slope; ${ }^{2}$ gradient of the slope across which the bolder moves.

The total basal area $\left(T B A, \mathrm{~m}^{2} / \mathrm{ha}\right)$ is calculated following:

$T B A=$ Stand Density $\times \pi \times(D B H / 200)^{2}$

where the $D B H$ is given in $\mathrm{cm}$. Figure 5 shows the distribution of stem $D B H$ per hectare at each stand. The Bystřička site has sparsely distributed large trees. Given total basal area approaches $10 \mathrm{~m}^{2} / \mathrm{ha}$, under which the forest has almost no rockfall mitigation effect (Berger, Dorren 2007).

Risk assessment for the Bystřička site was done using basic risk concept (Glade, Anderson, Crozier 2006). All elements at risk were mapped on site and their monetary value was estimated according the market property prices usual in the area. Risk of falling rock on presented elements at risk was calculated as follows:

$$
R=S P \times P R H \times(V \times \$)
$$

where $R$ is risk, $S P$ is spatial probability of the house being hit by a boulder (calculated as the ratio of the house width potentially hit by the boulder to total transversal slope width through which the stone may fall), $P R H$ stands for probable rockfall hazard calculated by Rockfor.net software, $V$ is estimated vulnerability of the houses or persons inside them and $\$$ represents assumed monetary value of the element at risk. This term was avoided when calculating individual risk for persons inside the buildings. 


\section{Rockfall hazard calculation}

The results confirmed that rock size is the most important variable affecting rockfall hazard defined as percentage of rocks that surpass the forested zone. With decreasing volume, $P R H$ also decreases (Tab. 1).

Highest $P R H$ values for all boulder sizes were calculated at the Bystřička site regardless the fact that initial energy of boulders is smallest due to $0 \mathrm{~m}$ initial fall high (place of detachment). $13 \%$ of the smallest boulders $\left(0.16 \mathrm{~m}^{3}\right)$ would pass the slope and almost $90 \%$ of the largest boulders $\left(3.52 \mathrm{~m}^{3}\right)$. The results can be explained by high slope gradient and relatively open forest with low protective capacity.

The smallest rockfall hazard was modeled at the Suchá Kamenice site, where high tree basal area gives the forest high protective capacity. Moreover there is relatively short and gentle slope below cliff with only $17 \mathrm{~m}$ height. The model shows that all rocks with volume equal or smaller than $0.52 \mathrm{~m}^{3}$ would be retained by the forest and only $27 \%$ or rocks with volume of $3.59 \mathrm{~m}^{3}$ would pass through the forested slope. Forest at the Suchá Kamenice has highest protective capacity from all tested sites.

Results of the Obecní důl site resemble the Bystřička site with slightly smaller $P R H$ values. The forest is capable of preventing smallest boulders to pass through the slope down the road. Nevertheless $83 \%$ of all boulders with size of $3.59 \mathrm{~m}^{3}$ would pass the slope. Comparison of $P R H$ values at the studied sites is well visible at the Figure 6.

Protective effect of forest was tested by changing the actual forest composition to forest composed entirely by locust (Pseudoacacia communis, Tab. 2) leaving the other characteristics unchanged. Such a change of specie composition considerably decreases the $P R H$ values at all sites. The improved protection capacity of the forest is especially clear for smaller boulders (up to $0.3 \mathrm{~m}^{3}$ ). Nevertheless this effect is negligible for the largest boulder size at the Bystřička test sites and more effective at the Obecní důl reflecting its high stem density. The strongest effect on rockfall hazard mitigation has the tree composition change at the Suchá Kamenice site, where the hazard for the largest boulder decreased from $27 \%$ down to $1 \%$ of $P R H$.

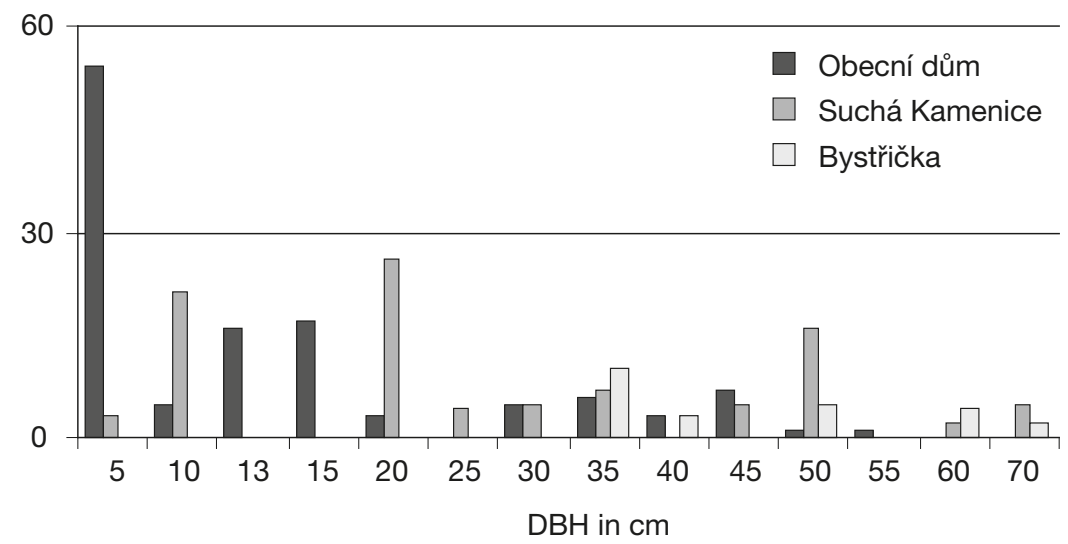

Fig. 5 - Frequency distribution of $\mathrm{DBH}$ (diameter at breast height) per ha at each test site 
Table 2 - Probable rockfall hazard

\begin{tabular}{|lcccc|}
\hline Test site & \multicolumn{4}{c|}{ Rock volume $\left(\mathrm{m}^{3}\right)$ and PRH $(\%)$} \\
\cline { 2 - 5 } & $3.59 \mathrm{~m}^{3}$ & $0.52 \mathrm{~m}^{3}$ & $0.3 \mathrm{~m}^{3}$ & $0.16 \mathrm{~m}^{3}$ \\
\hline Obecní důl & 83 & 38 & 10 & 1 \\
& $55^{*}$ & $1^{*}$ & $1^{*}$ & $1^{*}$ \\
\hline Suchá Kamenice & 27 & 1 & 1 & 1 \\
& $1^{*}$ & $1^{*}$ & $1^{*}$ & $1^{*}$ \\
\hline Bystř́ička & 89 & 60 & 43 & 13 \\
& $79^{*}$ & $22^{*}$ & $1^{*}$ & $1^{*}$ \\
\hline
\end{tabular}

Note: * calculations with forest composed of $100 \%$ locust trees for four rock sizes at the three test sites

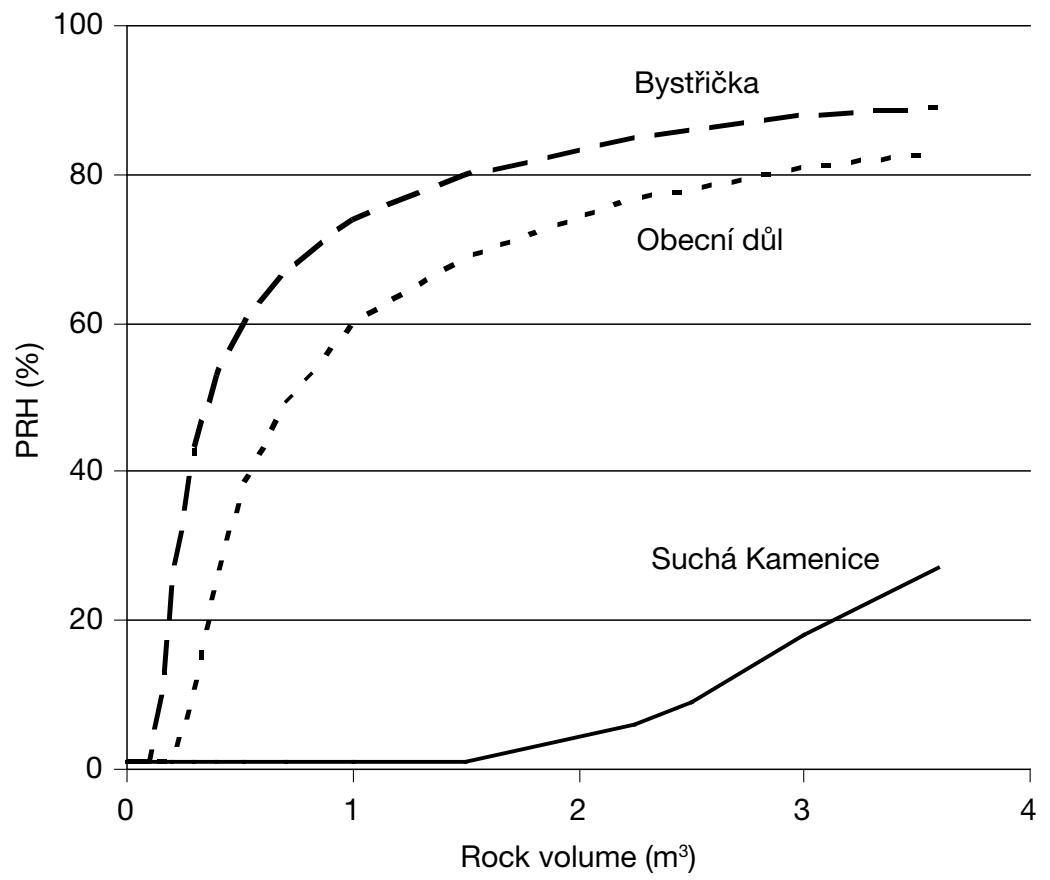

Fig. 6 - Relationship between rock volume $\left(\mathrm{m}^{3}\right)$ and $\mathrm{PRH}(\%)$ at each test site

In addition to the $P R H$ calculation, the Rockfor.net software provides a description of the target forest, which would be able to stop the modeled boulder size. In the case of the boulder with volume of $3.59 \mathrm{~m}^{3}$ at the Obecní důl site the target stand density is $17,120-18,830$ stems per ha and mean tree diameter is $30-40 \mathrm{~cm}$ if maintaining the forest original composition. Target forest composed uniquely of locust would require considerably lower density $(6,530-7,180$ stems per ha) with the same $D B H$. All these values are far above the actual stand density of 842 stems per ha and $15 \mathrm{~cm}$ of $D B H$ (Tab. 1) and are unrealistic to achieve. 


\section{Rockfall hazard and risk calculation at the Bystřička site}

All the presented models are parametric studies of different rock fall sizes except the $3.59 \mathrm{~m}^{3}$ boulder fall at the Bystřička site, which happened on the July 6th 1997 (Kirchner, Krejčí 1997; Krejčí at al. 2002). The 86\% PRH characterise event during which the boulder fall into the summer camp located on a flat area bellow the slope. Fortunately no one was hurt. Recent field observation at the site verified the conclusion of Kirchner and Krejčí (1997) that even larger boulders (estimated volume of about $19.39 \mathrm{~m}^{3}$ ) can fall from the same location. In this case the $P R H$ calculated is $96 \%$.

Using the $P R H$ as hazard description, partial risk is calculated for scenario considering the observed boulder size $\left(3.59 \mathrm{~m}^{3}\right)$ falling from the same source area. Elements at risk are one weekend house and commercial recreation facility offering accommodation. Spatial probability of hitting the elements at risk was calculated as a ratio of the total summed up width of elements at risk being possibly hit by the rockfall $(14 \mathrm{~m})$ to the slope section through which the possible rockfall may pass $(40 \mathrm{~m})$. The spatial probability is 0.35 . Estimated vulnerabilities of the houses related to the boulder size are shown in Table 3. Person vulnerability inside the house is always higher, since the resulting injuries may result also from falling debris of the house. Building vulnerability of 0.85 means almost entire destruction by the rock whereas 0.3 represent only minor damage to the construction. These vulnerabilities are based on the expert knowledge. Monetary value of weekend house calculated as an average price of 5 similar buildings offered by real-estate agencies nearby is 0.9 mil CZK (36,000 EUR) and the price of the commercial recreation facility was estimated to 4 mil CZK (160,000 EUR). Resulting partial risk calculated for the buildings and persons in the buildings is shown in Table 3.

\section{Discussion}

The Rockfor.net tool is not capable to assess when the next rockfall could be expected at a given site. Thus the probable rockfall hazard $(P R H)$ does not describe time constraints of the dangerous processes. From this point of view the used term "hazard" is partly misleading (Glade, Anderson, Crozier 2006).

Table 3 - Vulnerability associated with different boulder volume scenarios for the Bystřička site and calculated risk for each scenario

\begin{tabular}{|llcccc|}
\hline Test site & $\begin{array}{l}\text { Elements } \\
\text { at risk }\end{array}$ & \multicolumn{4}{c|}{ Rock volume and vulnerability } \\
\cline { 2 - 6 } Bystřička & $\begin{array}{l}\text { person } \\
\text { in building }\end{array}$ & 0.9 & $0.52 \mathrm{~m}^{3}$ & $0.3 \mathrm{~m}^{3}$ & $0.16 \mathrm{~m}^{3}$ \\
\cline { 2 - 6 } & building & 0.85 & 0.85 & 0.5 & 0.4 \\
\hline Risk & $\begin{array}{l}\text { person } \\
\text { in building }\end{array}$ & 0.27 & 0.15 & 0.046 & 0.3 \\
\hline $\begin{array}{l}\text { building } \\
\text { (in mil. CZK) }\end{array}$ & 1.25 & 0.6 & 0.22 & 0.18 \\
\hline
\end{tabular}


Alternation of tree composition has very strong effects on forest rockfall protective function according the Rockfor.net results. Changing the tree composition to uniquely locust trees decrees $P R H$ values. It is probably due to better energy dissipation caused by wood characteristics, e.g. its strength and elasticity. Thus it may be one mitigation option. Nevertheless, its application has certain limits and difficulties discussed also by Bigot, Dorren, Berger (2009). Firstly, some rockfall sites are located within the protected areas, where introducing exotic tree species (e.g. locust) may impossible in terms of local flora protection. Secondly, before introducing such mitigation measures, it is important to verify that the boulder size of expected rockfalls match the size for which the forest protective function would be considerably improved by changing the tree composition. From this point of view none of the selected test sites seems to be suited for applying such a mitigation measure, since the expected boulder sizes in all cases are too large to be effectively retained by the forest. However, in combination with technical protective measures, the forest always has a valuable, cost effective mitigation effect on rockfall.

Similarly, limitations of forest protection appear when considering the suggested target forest conditions ensuring the PRH of $1 \%$ calculated by the Rockfor.net for the test sites. The forest densities suggested by the software for the largest boulder size are simply too high to be realistic. Forest protective function is also limited by short length of the forested slope between the rockfall source and accumulation area at the sites.

Risk values calculated for the Bystřička site are only partial since time probability of rockfall occurrence is missing. The absence of time probability of rockfall or landslide occurrence is frequent in literature and is caused by the lack of information necessary for reliable time probability calculation or estimation. In the case of the Bystryička site the only way ho to obtain the time probability is to conduct detailed engineering-geological study calculating actual factor of safety of the landslide accumulation (considering also the already applied structural measures), which is source of possible future rockfalls. Then it would be possible to determine required amount of precipitation leading to destabilizing the landslide accumulation and exceeding probability of the required precipitation could be calculated and used as time probability of new rockfall occurrence.

Since such a study is not available we introduced time probability into the risk calculation assuming that similar conditions as those in July 1997 are required to initiate new rockfall. Another assumption that applied structural mitigation measures are not effective enough to permanently stabilize the landslide accumulation zone was also adopted. Under such conditions the time probability equals mean recurrent interval of the highest daily precipitation totals calculated for the July 6th 1997. According to Hladký (ed., 1998) it is $251-500$ years. This gives probability of the rockfall occurrence $10^{-3}$ per year and is a rather optimistic estimate since observation of recent stability conditions suggests that smaller amount of precipitation would be sufficient to mobilize boulders from the landslide accumulation area. When applying the estimated time probability to the calculated partial risk for persons in buildings, which is $10^{-1}-10^{-3}$ values of $10^{-4}-10^{-6}$ are gained. These values are within or bellow the maximum acceptable individual risk of $10^{-4}$ per year for the already build up areas (ERM-Hong Kong, Ltd. 1998). Values for individual 
risk $\left(10^{-1}-10^{-3}\right)$ calculated without time probability are too high requiring risk reduction effort. The responsible authorities may consider this alarming result as risk scenario. In such a case, careful examination of the already applied mitigation structures is recommended to see if they effectively reduce the rockfall occurrence probability resulting into acceptable individual risk values. Until this is done it is highly recommended to place warning signs alerting the inhabitants and visitors of the possible danger as was already suggested by Kirchner and Krejčí (1997).

\section{Conclusions}

The site specific application of the Rockfor.net software combined with identification of areas most susceptible to rockfalls and realistic estimation of the falling boulder sizes is very useful tool for assessing protective function of forest and can be used for realistic rockfall hazard assessment and evaluation of possible hazard management measures. At the Bystřička test site, it was shown that the realistic assessment of the rockfall forest protective function can be also useful in calculating rockfall risk for buildings and persons in the buildings. Even though, only partial risk was ascertained, it can be used to draw useful suggestions for local authorities regarding the safety considerations of the elements at risk.

\section{References:}

BERGER, F., DORREN, L.K.A. (2007): Principles of the tool Rockfor.net for quantifying the rockfall hazard below a protection forest. Scheiz Z Forstwes, 158, No. 6, pp. 157-165.

BIGOT, CH., DORREN, L.K.A., BERGER, F. (2009): Quantifying the protective function of a forest against rockfall for past, present and future scenarios using two modeling approaches. Nat Hazards, 49, pp. 99-111.

DORREN, L.K.A. (2003): A review of rockfall mechanics and modelling approaches. Progress in Physical Geography, 27, No. 1, pp. 69-87.

ERM-Hong Kong, Ltd. (1998): Landslides and boulder falls from natural terrain: interim risk guidelines. Geo Report No. 75, ERM-Hong Kong, Ltd, Hong Kong, 183 pp.

GLADE, T., ANDERSON, M., CROZIER, M.J. (2006): Landslide Hazard and Risk. John Wiley \& Sons Ltd, Chichester, 802 pp.

GUZZETTI, F., CROSTA, G., DETTI, R., AGLIARDI, F. (2002): STONE: a computer program for the three-dimensional simulation of rock-falls. Computers \& Geosciences, 28, No. 9, pp. 1079-1093.

HARTVICH, F., RYBÁŘ, J. (2011): Zřícení skalní věže Pinta na západním okraji Příhrazské vrchoviny. In: Jenč, P., Šoltýsová, L. (eds.): Pískovcový fenomén Českého ráje II. Turnov, in print.

HLADKÝ, J., ed. (1998): Vyhodnocení povodňové situace v červenci 1997 - souhrnná zpráva projektu MŽP ČR. MŽP ČR, Praha, http://www.chmi.cz/hydro/souhrn/obsah.html, (last visited 3.1.2007).

KIRCHNER, K., KREJČÍ, O. (1997): Předběžná zpráva o studiu sesuvů aktivovaných během extrémní srážkové činnosti v červenci 1997 na okrese Vsetín. ČGÚ, Ústav geoniky AV ČR, Brno, $105 \mathrm{~s}$.

KREJČİ, O., BAROŇ, I., BÍL, M., JUROVÁ, Z., HUBATKA, F., KIRCHNER, K. (2002): Slope movements in the Flysch Carpathians of Eastern Czech Republic triggered by extreme rainfalls in 1997: a case study. Physics and Chemistry of the Earth, 27, 2002, Pergamon, pp. 1567-1576. 
ZVELEBIL J. (1989): Inženýrskogeologické aspekty vývoje skalních svahů v Děčínské vrchovině. Ph.D. thesiss, Charles University, Praha, 282 pp.

ZVELEBIL, J., VAŘILOVÁ, Z., PALUŠ, M. (2005): Tools for rock fall risk integrated management in sandstone landscape of the Bohemian Switzerland National Park, Czech Republic (M121). In: Sassa, K., Fukuoka, H., Wang, F., Wang, G. (eds.): Landslides - Risk Analysis and Sustainable Disaster Management. Springer, pp. 119-126.

ZVELEBIL, J., VAŘILOVÁ, Z., PALUŠ, M. (2008): New Challenges for Mathematics in Safety Momitoring of Rock Slopes: The Third Wave. In: Proceedings of The First Landslide Forum. ICL, ISDR, Tokyo, pp. 705-708.

Next sources:

Na silnici ve Hřensku se zřítila skála, tah do Německa zablokován. Novinky.cz; www.novinky.cz/krimi/181642-na-silnici-ve-hrensku-se-zritila-skala-tah-do-nemecka-zablokovan. html (last visited 12.1.2010).

Farm Forest Line. Australan Forest Growers, Melbourne University School of Resource Management, www.farmforestline.com.au (last visited 12.1.2010).

\section{Shrnutí}

\section{HODNOCENÍ OHROŽENÍ A RIZIKA VZNIKU SKALNÍCH ŘÍCENÍ NA ZALESNĚNÝCH SVAZÍCH, PŘÍKLADY Z ČESKA}

Program Rocfor.net byl vytvořen k hodnocení pravděpodobnosti průchodu (pádu) balvanu po zalesněném svahu (Berger, Dorren 2007). Program považuje les za soustavu záchytných sítí, které jsou představovány řadami stromů o určitém druhovém složení, průměru kmene a hustotě zapojení. Program určí počáteční energii balvanu, kterou získá pádem ze skalní stěny nebo pádem po příkrém svahu. Poté na základě vložených informací o středním průměru stromů, jejich hustotě na hektar a druhovém složení program vypočítá pravděpodobný počet dopadů balvanu na jednotlivé stromy a velikost energie, které bude těmito dopady spotřebována. Porovnáním tohoto výsledku s výpočtem počtu dopadů balvanu na stromy, který by zajistil, aby se balvan zastavil na zalesněném svahu, vypočítá Rockfor.net pravděpodobnost, s jakou modelovaný balvan projde lesním porostem (Berger, Dorren 2007). Je tak možné zhodnotit pro konkrétní zalesněný svah do jaké míry může zabránit balvanům o určité velikosti dopadnout např. na silnici nebo domy na jeho úpatí. Program nezohledňuje ploché části reliéfu nebo ztrátu energie $\mathrm{v}$ důsledku tření $\mathrm{s}$ povrchem svahu během pádu balvanu.

Program byl aplikován na dvou svazích v údolí Labe, jižně od města Hřenska a na lokalitě pod hrází přehradní nádrže Bystřička ve stejnojmenné obci. Ve všech případech byly modelovány pískovcové balvany o teoretické velikosti. Ukázalo se, že na výsledek má největší vliv velikost balvanu. V případě největšího modelovaného bloku o objemu $3,59 \mathrm{~m}^{3}$ nebyl lesní porost na žádné z lokalit schopen výrazně snížit pravděpodobnost pádu balvanu k patě svahu. Nejvyšší nebezpečí (95\% pravděpodobnost pádu balvanu přes zalesněný svah) bylo vypočítáno pro lokalitu Obecní důl u Hřenska, kde na vysoký skalní útes $(36 \mathrm{~m})$ navazuje relativně strmý svah $\left(29^{\circ}\right)$. Výpočty ukázaly, že vliv morfologie reliéfu a velikosti balvanu výrazně převažuje nad vlivem lesního porostu na pravděpodobnost pádu balvanu k patě svahu. Nicméně zajímavé výsledky přinesla změna druhového složení lesa. V případě, že les by byl tvořen ze $100 \%$ akáty (Pseudoacacia communis), snížila by se pravděpodobnost průchodu balvanu takovýmto porostem v některých případech o více než 30-50 \%.

$\mathrm{V}$ případě obce Bystřička představoval jeden z modelovaných balvanů reálnou událost ke které došlo v červenci 1997, kdy z akumulace drobného sesuvu došlo k uvolnění pískovcového balvanu a jeho pádu do rekreačního areálu (Krejčí, Kirchner 1997). V tomto př́ípadě bylo také vypočítáno částečné kvantitativní riziko vzniku obdobné události. Vypočítané riziko je nutné chápat pouze jako scénář možného vývoje dané lokality a nikoliv jako hodnotu představující současné reálné riziko. Pro takovýto dostatečně spolehlivý výpočet nejsou k dispozici zásadní informace zahrnující pravděpodobnost vzniku řícení o stejné velikosti jako v roce 1997 a zranitelnost budov ohrožených tímto řícením. Překonání první překážky by vyžadovalo realizaci podrobného inženýrsko-geologického průzkumu akumulace sesuvu, 
která slouží jako zdrojová oblast řícení. Přesné vyčíslení zranitelnosti budov by bylo možné pouze na základě podrobné znalosti jejich konstrukce a také ceny pro určení škod vzniklých v důsledku jejich poškození. Tato čísla byla při výpočtu částečného rizika nahrazena odhady. Pravděpodobnost vzniku řícení nereflektovala současnou stabilitní situaci a vycházela z hodnoty střední doby opakování nejvyšších denních srážek vypočítaných pro srážkové úhrny z 6.7.1997, kdy došlo ke vzniku sesuvu a následnému řícení balvanu. Míra poškození budov a jejich cena byla odhadnuta na základě literatury a cen realit ve stejné lokalitě. Do výpočtu rizika vzniku skalního řícení byla dále zahrnuta pravděpodobnost průchodů balvanu lesním porostem vypočítaná programem Rockfor.net. Takto vypočítané riziko se pohybuje v rozmezí maximálních hodnot $10^{-4}-10^{-6}$ pro již zastavěné lokality navržené metodikou ERM (Hong Kong, Ltd. 1998). Nicméně riziko pro budovy nebo jejich obyvatele vypočítané pro případ, že by znovu došlo ke stejnému řícení jako v roce 1997 je o několik řádů vyšší $\left(10^{-1}-10^{-3}\right)$ a naznačuje, že by se situací na zkoumaném místě měla vážně zabývat místní samospráva.

Obr. 1 - Přehled studovaných lokalit

Obr. 2 -Detailní pohled na pískovcovou stěnu na lokalitě Obecní důl

Obr. 3 - Topografické profily studovaných lokalit s vyznačeným místem původu skalního bloku (d) a místem jeho dopadu (a)

Obr. 4 - Pohled na lesní porost a ohrožené domy na lokalitě Bystřička

Obr. 5 -Zastoupení $D B H$ (diameter at breast height - průměr ve výšce hrudi) na hektar pro jednotlivé studované lokality

Obr. 6 -Vztah mezi objemem balvanů $\left(\mathrm{m}^{3}\right)$ a $P R H(\%)$ na studovaných lokalitách

Authors' affiliations: Ústav struktury a mechaniky hornin AV ČR, v. v. i., V Holešovičkách 41, Praha,Czechia; e-mail:jklimes@centrum.cz.

Initial submission, 17 January 2010; final acceptance, 5 March 2011.

Please cite this article as:

KLIMEŠ, J. (2011): Rockfall hazard and risk assessment on forested slopes, examples from Czechia. Geografie, 116, No. 2, pp. 144-155. 